\title{
DARWINISME SOSIAL DAN KEAMANAN \\ INTERNASIONAL: \\ SEBUAH ANALISIS RINGKAS
}

\author{
Ariesani Hermawanto \\ email : ariesanihermawanto@gmail.com \\ Jurusan Ilmu Hubungan Internasional \\ Fakultas Ilmu Sosial dan Ilmu Politik UPN “Veteran” Yogyakarta
}

\begin{abstract}
The development of socio-biology science brings changes to the security of human social life. The biological theory about evolution made discussion that was identified as Social Darwinism. This thought was based on assumptions that human life through natural selection and always in conflict by competition to fight for life, keep the existence, and also survival of the fittest. Social Darwinism in its history produced ideology like Fascism and has made tragedies in the eras of World Wars I and II. As a thought, Social Darwinism still continues today.The competition between countries in the new Millennium era, both in the arms race and economic competition, are reflection of Darwinist thougt.
\end{abstract}

Keywords : evolution Social Darwinism conflict security

\section{Pendahuluan}

Perkembangan studi ilmu biologi berdampak besar terhadap studi-studi sosial maupun politik yang berkorelasi pada kehidupan manusia. Perkembangan pesat ilmu biologi sejak abad ke 18 setelah sistem klasifikasi dari Linnaneus (1758) membawa perubahan sudut pandang mengenai era perjalanan sejarah manusia. ${ }^{1}$ Hal ini didasarkan kenyataan bahwa manusia secara biologis tidak banyak berbeda dengan makhluk hidup yang lain; yang berkembang biak, memerlukan regenerasi, berkompetisi dengan makhluk hidup lain, menempati tempat dan ruang tertentu, mempunyai karakter khusus, kemampuan mempertahankan diri yaitu bagaimana makhluk hidup itu mempertahankan

\footnotetext{
${ }^{1}$ Carolus Linnaneus (1707-1708) adalah seorang ahli biologi dari Swedia yang menulis buku Systema Naturae (The System of Nature) pada tahun 1758. Linnaneus disebut sebagai "Father of Taxonomy" serta orang pertama yang merintis studi dari ekologi; yang menggambarkan adanya hubungan erat antara kehidupan makhluk hidup dengan lingkungannya.
} 
eksistensinya. Di dalam konteks kelompok, manusia merupakan mamalia sosial dan politik dimana mereka dapat mengenali diri mereka sebagai individu-individu yang membentuk ikatan genuine dalam kumpulan yang berpikiran sama. ${ }^{2}$

Kehidupan manusia tergolong masih muda jika dibandingkan dengan makhluk hidup yang lain. Terdapat sejumlah spesies dari manusia yang pernah tinggal di bumi, dan spesies itu berganti-ganti hingga masa sekarang yaitu era homo sapiens. ${ }^{3}$ Perubahan yang terjadi dari spesies manusia satu menjadi spesies yang lain, ataupun bersifat menggantikan memerlukan proses yang lama; memerlukan perubahan melalui proses yang disebut dengan evolusi. ${ }^{4}$ Perkembangan secara evolusionis ini juga terjadi pada makhluk hidup lain seperti binatang. Dengan kata lain terdapat kesamaan antara ciri dari makhluk hidup, baik itu binatang maupun manusia, yaitu mereka mengalami perubahan secara perlahan-lahan, dalam rentang waktu tertentu serta dipengaruhi banyak faktor seperti kemampuan mereka untuk mempertahankan diri. Pandangan bahwa kehidupan itu berubah secara evolusi disampaikan sejumlah ilmuwan seperti Jean B. Lamarck, Charles Darwin dan juga Gregor Mendell. Diantara ilmuwan ini yang menimbulkan dampak paling kontroversial adalah pemikiran evolusi dari Charles Darwin; melalui sebuah bukunya yang terkenal yaitu The Origin of Species : By Means of Natural Selection, or the Preservation of Favoured Races in the Struggle for Life yang diterbitkan pertama kali tahun 1859 dan buku The Descent Man yang terbit tahun 1871.

Mengapa pemikiran evolusi Darwin ini kemudian menjadi satu pembahasan penting? Hal ini tidak lepas dari adanya ide-ide dan konstruksi pemikiran yang

\footnotetext{
${ }^{2}$ Clark ,Stephen R.L. (1999). The political animal: Biology, ethics and politics, Routledge: London. p 110.

${ }^{3}$ Terdapat sejumlah ras manusia yang pernah menghuni bumi hingga era ras homo sapiens seperti sekarang. Era sebelum homo sapiens terdapat ras manusia lain yang menghuni bumi yang dikenal sebagai homo Neanderthal yang sekarang telah musnah. Mengenai perkembangan ras manusia hingga homo sapiens ini, baca Frederick L. Coolidge and Thomas Wynn. 2009. The Rise of Homo sapiens : The Evolution of Modern Thinking, John Wiley \& Sons Ltd: The Atrium UK.

${ }^{4}$ Teori evolusi menyatakan bahwa makhluk hidup secara natural mengalami perubahan secara terus-menerus yang berbeda dari pendahulunya. Pada masa sekarang, para ahli biologi mengatakan evolusi merupakan fakta di dalam kehidupan yang sesuai dengan penemuan saintifik. Pengaruh pemikiran evolusi telah menyebar bukan hanya dalam studi biologi namun juga pada studi filsafat, sosial dan politik; bahkan sebenarnya setiap pemikiran manusia pada dasarnya dipengaruhi evolusi ini. Selanjutnya bisa dibaca dalam: Jan Sapp. 2003. Genesis: The Evolution of Biology, Oxford University Press: New York.
} 
didasarkan pada asumsi-asumsi biologi versi Darwin yang diaplikasikan ke dalam dunia sosial manusia. Berdasarkan pemikiran evolusi ini maka kehidupan sosial manusia sesuai dengan rentang waktu sejarahnya, pada dasarnya dibentuk melalui proses yang berlangsung secara evolusionis. Masyarakat-masyarakat di seluruh dunia ada sebagai hasil dari evolusi yang berlangsung melalui banyak konflik dan penyesusaian. Bisa dikatakan bahwa pola kehidupan sosial yang natural adalah berdasarkan evolusi tersebut.

Pemikiran mengenai evolusi dari Darwin ini selanjutnya menjadi basis pijakan dari ideologi-ideologi yang mendasarkan asumsinya pada proses evolusi ini. Ideologi tersebut beranjak dari asumsi bahwa manusia pada dasarnya tidaklah egaliter dan selalu ada dalam kondisi konfliktual, sama seperti kehidupan binatang pada umumnya. Selain itu ideologi ini percaya terdapat keunggulan ras manusia tertentu dibandingkan ras manusia yang lain. Oleh karena itu akan selalu terjadi proses seleksi alam berupa pertarungan antara ras unggul berhadapan dengan ras lain yang dipandang rendah. Pemikiran seperti ini yang selanjutnya secara praktikal diadopsi sebagai ideologi sosial dan politik dan dijalankan melalui sistem kenegaraan. Ideologi yang didasarkan pemikiran dari Darwin seperti ini adalah Fascisme yang muncul di Italia dan Jerman tahun 1930-an. Sedangkan sebagai pengembangan pemikiran, asumsi evolusionis yang disampaikan oleh Darwin ini termanifestasikan dalam banyak ideologi lain seperti Marxisme-Komunisme berkaitan dengan dialektika konfliktual dan juga kapitalismemerkantilisme yang menyebabkan imperialisme dan kolonialisme di banyak wilayah di dunia. $^{5}$

Karya akademik Charles Darwin, seorang ilmuwan biologi, telah menjadi dasar bagi munculnya pemikiran yang dikenali dengan Darwinisme; yang dalam tahap selanjutnya menghasilkan apa yang disebut dengan Darwinisme Sosial. Pemikiran akademik berbasis materialisme ini di dalam prakteknya telah berdampak pada dinamika politik dan keamanan internasional dalam skala global. Dinamika tersebut

\footnotetext{
${ }^{5}$ Ideologi-ideologi itu bersumber dari sebuah pemikiran filsafat yang berlandaskan pada filsafat materialism, yang berbasis pada alam secara material semata-mata.
} 
bahkan berlangsung hampir di sepanjang abad ke-20 hingga hingga awal millenium baru abad ke-21.

Tulisan ini bertujuan untuk menguraikan apa yang dimaksud Darwinisme Sosial, dengan sudut pandang dimulai dari dinamika konflik dalam kehidupan, serta pengaruhnya terhadap pemikiran dan praktek politik internasional sejak pemikiran tersebut muncul hingga masa sekarang.

\section{Kerangka analisis : konflik dan proses evolusi}

Di era sejarah modern, abad ke-20 menjadi abad yang penuh dengan konflik, perang dan tragedi kemanusiaan. Terdapat banyak pertikaian di antara negara-negara di dunia yang menyebabkan jutaan manusia terbunuh, pembantaian massal, kehancuran fisik maupun non-fisik serta kemiskinan yang mencapai titik ekstrem. Salah satu sumber dari tragedi dunia itu adalah pemikiran manusia yang berbentuk ideologi serta menjadi dalih pembenar adanya konflik. Ideologi telah menjadi sumber konflik, dimana sejumlah negara menjadi teman dan sekutu dan sebagian lain adalah musuh. Alasan yang mendasari adalah lawan itu muncul akibat perbedaan ideologi dan cara pandang mengenai tata dunia yang ingin dibuat. Arus utama studi mengenai ideologi juga berkaitan dengan teori kepentingan, dimana ideologi telah menjalankan fungsi sebagai upaya mendapatkan atau menjaga keunggulan kelompok tertentu. Kepercayaan ideologis dianggap sebagai respon bawah sadar untuk dislokasi dalam struktur sosial. ${ }^{6}$

Kepercayaan ideologis itu terdiri dari serangkaian ide yang dipegang erat oleh suatu kelompok. Ideologi dari individu tertentu boleh jadi mewakili, atau mengklaim mewakili kepentingan bersama. Keyakinan ideologis menyediakan interpretasi yang luas mengenai kondisi manusia; yang memerlukan sebuah kesadaran sejarah (historical consciousness) dari masa lalu dan masa depan. ${ }^{7}$ Bisa dicontohkan di sini adalah munculnya ideologi Fascism dan Komunisme, yang bertujuan untuk merekonstruksi kehidupan manusia dan membuat masa depan seperti yang ideologi tersebut bayangkan. Ideologi Fascisme dan Komunisme telah muncul sebagai ideologi yang saling

\footnotetext{
${ }^{6}$ Cassels, Alan. 1996. Ideology and international relations in the modern world, Routledge : London, p 5.

${ }^{7}$ Cassel, ibid, p 6.
} 
berkonflik dan bersifat menghancurkan satu sama lain; bahkan bertentangan dengan ideologi-ideologi yang sebelumnya sudah eksis.

Konflik pada dasarnya adalah fenomena yang umum terjadi di dalam kehidupan sosial. Kajian-kajian mengenai konflik banyak dilakukan oleh para ilmuwan untuk menjelaskan apa yang dimaksud dengan konflik ditinjau dari sejumlah aspek yang berbeda-beda. Konflik berasal dari kata Latin conflictus, dari conflīgere yaitu bertempur, dari fligere yaitu menyerang. Konflik menurut Merriam-Webster Dictionary bermakna sebagai “competitive or opposing action of incompatibles, antagonistic state or action-as of divergent ideas, interests, or persons”. Konflik juga bermakna 'mengejutkan atau menyerang bersama' (shocking or strike together), diterjemahkan sebagai sebuah kejutan yang dapat menimbulkan kebencian yang dinyatakan dengan kekerasan. Johan Galtung memaknai istilah 'mengejutkan bersama' itu sebagai "goals held by the parties when the realization of one excludes the realization of other(s)." Ini menunjukkan bahwa konflik adalah suatu kondisi ketidakcocokan atau adanya kontradiksi tujuan. ${ }^{8}$ Konflik juga didefinisikan sebagai situasi di mana aktor-aktor saling berperilaku melawan pihak lain untuk mencapai tujuan mereka yang tidak bersesuaian (incompatible goals) serta untuk mengekspresikan permusuhan mereka. ${ }^{9}$

Kehidupan manusia ditandai oleh fenomena konflik dan kerjasama, serta menjadi bagian perkembangan biologis manusia sesuai dengan sejarah evolusi makhluk hidup. Goldsmith mengatakan bahwa evolusi manusia didorong oleh fenomena bagaimana orang-orang bekerja sama dan bersaing didalam kelompok dan antar kelompok untuk akses ke sumber daya (resources); yang berkaitan dengan bagaimana mereka melihat dunia dan berhubungan satu sama lain. ${ }^{10}$ Selanjutnya dijelaskan pula, bahwa secara evolusionis otak manusia telah dibentuk melalui proses interaksi perilaku yang bersifat egois dan juga kooperatif di dalam kelompok, dimana pada saat yang sama

\footnotetext{
${ }^{8}$ Galtung, Johan.2007. Peace by peaceful conflict transformation - theTranscend Approach, chapter 2 pp 14-32, in, Webel, Charles and Galtung,Johan (eds).2007. Handbook of Peace andConflict Studies, Routledge: New York, p 22.

${ }^{9}$ Bartos, Otomar J. and Wehr, Paul. 2002. Using Conflict Theory, Cambridge University Press:New York, p 13.

10 Goldsmith, Timothy H.(1991). The biological roots of human nature: forging links between evolution and behavior, Oxford University Press : New York, p 121.
} 
didorong adanya persaingan ketat antar kelompok. Sejarah manusia sebagian besar merupakan catatan perjuangan untuk mengendalikan sumber daya oleh satu kelompok dengan mengorbankan yang lain. Pertikaian-pertikaian politik besar sejak jaman dahulu hingga masa sekarang hampir selalu mengarah pada konflik sumber daya; apakah itu tanah, air, mineral; atau di mana kombatan menempati wilayah yang sama, akses ke pekerjaan atau berkaitan dengan pembagian yang sesuai dari kekayaan yang dimiliki sebuah kelompok. ${ }^{11}$

Dalam konteks sosial, berkaitan dengan pola hubungan yang bersifat konfliktual, terdapat banyak pemikiran dari para ahli mengenai apa yang menjadi dasar dari adanya konflik di dalam kehidupan manusia. ${ }^{12}$ Salah satunya ditunjukkan oleh pemikiran dari Charles Darwin $(2009,1872)$ yang menunjukkan bahwa terdapat persaingan yang bersifat universal dari hubungan yang terjadi di dalam kehidupan, termasuk di dalamnya adalah manusia, dan berlangsung sebagai bagian dari proses evolusi makhluk hidup. ${ }^{13}$

\section{Darwin dan Darwinisme Sosial}

Darwin menunjukkan bahwa di dalam kehidupan terdapat satu hukum umum (one general law) yang mengarah kekemajuan semua makhluk organik, yaitu berkembang biak, bervariasi, serta membiarkan makhluk hidup terkuat tetap hidup dan yang terlemah mati. ${ }^{14}$ Hal tersebut berlangsung dalam suasana alamiah dimana makhluk hidup terus berjuang agar selalu eksis, dan di dalam proses itu secara evolusi bersifat menyeleksi serta disebut dengan istilah Seleksi Alam. Darwin (2009,1872:49) mengatakan $:^{15}$

"The offspring, also, will thus have a better chance of surviving, for, of the many individuals of any species which are periodically born, but a small number can survive. I have called this principle, by which each slight variation, if useful, is

\footnotetext{
${ }^{11}$ Goldsmith, ibid, p 121.

13 Darwin,Charles.(1872, 2009). The Origin of Species :By Means of Natural Selection, or the Preservation of Favoured Races in theStruggle for Life, first published 1876,Cambridge University Press : New York.

${ }^{14}$ Darwin, ibid, p 263.

${ }^{15}$ Darwin, ibid, p 49.
} 
preserved, by the term Natural Selection, in order to mark its relation to man's power of selection."

Dalam uraian tersebut ditunjukkan bahwa sebagaimana makhluk hidup yang lain, secara alamiah manusia berupaya menjaga eksistensinya dengan berkembang biak dan menghasilkan keturunan. Di dalam proses tersebut, menurut Darwin, hanya sebagian kecil yang mampu untuk terus bertahan dan survive.Hal tersebut tidak lepas dari adanya seleksi alamiah yang menggambarkan seleksi atas dasar kekuasaan dan kekuatan (power). Ini merupakan sebuah perjuangan untuk mempertahankan eksistensi (struggle for existence). Seleksi alam merupakan suatu proses yang tanpa henti dan tidak terelakkan, yang jauh lebih unggul dari segala upaya yang dibuat oleh manusia.Darwin juga menunjukkan bahwa seleksi alam berlangsung melalui proses evolusi. Di dalam proses secara alamiah ini, maka yang kuat akan mampu bertahan sedangkan yang lemah akan mengalami penurunan bahkan kemusnahan. Ini disebut sebagai kelangsungan hidup bagi yang terkuat (the survival of the fittest). ${ }^{16}$

Pemikiran Darwin mengenai makhluk hidup, termasuk manusia, berada dalam kondisi perjuangan untuk terus eksis, adanya seleksi alam yang sifatnya alamiah, serta yang kuat adalah yang mampu bertahan (the survival of the fittest). Pemikiran ini selanjutnya menghasilkan ajaran yang dikenal sebagai Darwinisme. Tulisan Darwin tersebut menunjukkan bahwa kehidupan makhluk hidup, termasuk di dalamnya manusia, berlangsung melalui proses perubahan yang sifatnya bertahap. Di dalam proses tersebut terjadi fenomena konfliktual sebagai proses yang sifatnya natural. Argumentasi Darwin itu kemudian diadopsi ke dalam dunia sosial manusia, yang melihat bahwa kehidupan manusia pun berlangsung melalui proses yang sifatnya konfliktual dan evolusionis. Ini adalah manifestasi dari apa yang disebut dengan Darwinisme Sosial dalam kehidupan. Sebagai sebuah pemikiran menjadi penting untuk didefinisikan secara lebih jelas apa yang dimaksud dengan Darwinisme Sosial tersebut. Secara simpel Darwinisme Sosial adalah "the explicit endorsement of Darwin's theory

${ }^{16}$ Darwin, ibid, p 62-105. 
of evolution“.${ }^{17}$ Ini merupakan sebuah ekspresi dari komitmen untuk memaparkan ideide dari Darwin dalam konteks teori sosial. ${ }^{18}$

Munculnya Darwinisme Sosial mengakibatkan terjadinya konflik dan perang dengan mendasarkan pada penguasaan pihak kuat terhadap pihak yang lemah; yang secara akademik dan ilmiah mendapatkan dukungan dan legitimasi. Dalam konteks sejarah, konflik memang merupakan fenomena kehidupan yang hampir setua umur manusia itu sendiri. Namun yang menarik dari pemikiran Darwin adalah, dia menunjukkan konflik adalah hal yang diperlukan dalam proses evolusi makhluk hidup termasuk manusia. Pemikiran yang demikian secara langsung kemudian berdampak pada keamanan kehidupan manusia itu sendiri, yaitu ketika pemikiran evolusionisme dalam kehidupan dijadikan akar dari konflik diantara manusia.

Ditinjau secara keilmuan Darwinisme itu sendiri merupakan sebuah teori biologis tentang bagaimana spesies baru terbentuk dan yang sudah ada bisa punah. Ini didasarkan pada pandangan "heredity generally acts as a force for species continuity...the process of natural selection which, over time, results in the appearance of new species and the elimination of others". ${ }^{19}$ Dalam konteks pemikiran Darwinisme ini, maka keturunan merupakan sebuah kekuatan bagi keberlangsungan hidup bagi spesies; di dalam konteks perubahan yang sifatnya evolusionis. Teori seleksi alam Darwin membentuk inti dari teori evolusi modern dan menjadi suatu pandangan dunia yang lebih luas (wider world view). ${ }^{20}$

Secara umum pandangan dunia yang dimaksud ini adalah bentuk dari sejumlah asumsi mengenai waktu dan sifat manusia yang relevan dengan teori Seleksi Alam. Asumsi-asumsi tersebut antara lain: ${ }^{21}$

(1) adanya hukum biologis yang mengatur keseluruhan organik alam, termasuk manusia. $^{22}$

\footnotetext{
${ }^{17}$ Moore, J.R.1980. Varieties of Social Darwinism, Open University Course, Conflictand Stabilityin the Development of Modern Europe, Milton Keynes: Open University Press, p 37.

${ }^{18}$ Hawkins, Mike.1997. Social Darwinism in European and American thought, 1860-1945: natureas model and nature as threat, Cambridge University Press : New York, $\mathrm{p} 6$.

${ }^{19}$ Hawkins, ibid, p 24.

${ }^{20}$ Teori evolusi modern didasarkan pada mutasi genetika

${ }^{21}$ Hawkins, ibid, p 30-31.
} 
(2) munculnya tekanan akibat pertumbuhan populasi pada sumber daya menghasilkan perjuangan untuk mempertahankan eksistensi di antara organisme.

(3) sifat fisik dan mental memberi keuntungan pada pemiliknya di dalam kompetisi mempertahankan hidup (termasuk di dalam kompetisi seksual) baik melalui warisan (inheritance) maupun menyebar melalui populasi

(4) efek kumulatif seleksidan pewarisan dari waktu ke waktu menyebabkan munculnya spesies barudan penghapusan pihak lain.

Di dalam perkembangan secara teoritik, selanjutnya muncul asumsi yang ke-5 sebagai konsekuensi dari keempat asumsi sebelumnya tersebut. Asumsi (5) ini adalah kaitan antara sifat fisik-biologis manusia dengan eksistensi dan sifat sosialnya. Asumsi ke-5 inilah yang kemudian melahirkan konsep yang dikenal sebagai Darwinisme Sosial (Social Darwinism); sebagaimana dikatakan Hawkins bahwa asumsi ke-5 ini bersifat krusial dalam konteks determinisme saintifik yang tidak hanya pada sifat fisik manusia namun juga eksistensi sosial mereka, beserta atribut-atribut psikologis yang memainkan peran mendasar dalam kehidupan sosial seperti alasan-alasan (reason), agama dan juga moralitas. ${ }^{23}$ Adalah memungkinkan dalam mendukung elemen asumsi 1-4 tanpa melibatkan asumsi ke-5. Sejumlah alasan disampaikan bahwa manusia adalah ciptaan yang khas yang berbeda dengan makhluk hidup yang lain; ataupun manusia adalah makhluk budaya, dimana budaya tidak dapat direduksi menjadi semata-mata prinsip biologis.

Akan tetapi, para ilmuwan pendukung Darwinisme Sosial menunjukkan bahwa banyak aspek budaya (jika tidak semua), seperti agama, etika, lembaga politik, timbul dan tenggelamnya imperium dan peradaban; serta banyak karakteristik psikologis dan tingkah laku yang dapat dijelaskan oleh asumsi 1-4 sebagaimana diuraikan sebelumnya. Menurut mereka terdapat dua fakta fundamental mengenai kehidupan alamiah manusia,

\footnotetext{
${ }^{22}$ Pada masa sekarang asumsi yang pertama ini merupakan salah satu bentuk determinisme saintifik (scientific determinism) yang menjadi pengorganisasian yang kuat bagi Darwin dan banyak ilmuwan lain, di dalam menentang pemikiran supernatural dan teleologis tentang pembentukan spesies (species formation).

${ }^{23}$ Hawkins, loc cit, p 31.
} 
yaitu sebagai kelanjutan dari psikologi binatang dan telah melalui evolusi berdasarkan seleksi alam. ${ }^{24}$

\section{Darwinisme sosial, konflik dan perang dalam perspektif evolusi}

Teori dari Darwin yang telah melahirkan pemikiran mengenai Darwinisme Sosial menghasilkan pemikiran bahwa konflik adalah bagian dari proses evolusi. Dalam konteks ini maka kehidupan selalu berada dalam kondisi konfliktual dan perang; yang merupakan proses seleksi alam. Perang secara saintifik adalah diperlukan sebab ras superior (superior race) akan menghilangkan ras inferior (inferior race), sebagai bagian dari evolusi, dan peradaban manusia tidak akan eksis jika tidak terjadi perang yang sifatnya konstan. ${ }^{25}$ Ras-ras superior yang menjadi kekuatan hegemonik ini diantaranya adalah ras Arya, ras Anglo-Saxon serta ras-ras kulit putih Western lain; sedangkan rasras inferior diantaranya adalah ras Afrika, ras Semit serta ras-ras non-Western lain.

Teori mengenai superioritas evolusioner dan munculnya dominasi hegemonik muncul di Eropa pada akhir abad ke-19 dan kemudian menyebar ke seluruh dunia. Teori evolusi dari Darwin menjadi dasar akademik dan ilmiah untuk diterapkan sebagai landasan dari ideologi politik. Konsep mengenai struggle of life, natural selection dan juga survival of the fittest telah menghasilkan pemikiran yang bersifat rasial, yang bertujuan untuk mengontrol dan meningkatkan kualitas manusia. Munculnya Darwinisme Sosial dan eugenics ${ }^{26}$ di Eropa abad ke-19 digunakan sebagai dasar bagi imperialisme serta menjadi bukti bagi adanya hegemoni, nasionalisme, xenofobia, dan etnosentrisme. ${ }^{27}$

Pengaruh pemikiran Darwinisme Sosial ini menyebabkan banyaknya terjadi perang besar di abad ke-20, termasuk di dalamnya adalah genocide dan penindasan atas

\footnotetext{
${ }^{24}$ Hawkins, loc cit, p 31.

${ }^{25}$ MacMaster, Neil.2001. Racism in Europe 1870-2000, Palgrave: New York, p 68.

${ }^{26}$ Eugenika (eugenics) merupakan program untuk mengontrol keturunan dan kehamilan yang melibatkan penggunaan kontrasepsi, aborsi, kontrol kesuburan, dan manipulasi ilmiah dari alam melalui seleksi buatan, dalam rangka menciptakan manusia super (ras unggul) dengan mencegah penyakit degenerasi dan yang tidak diinginkan dari reproduksi. Program eugenics ini selanjutnya berakibat pada pemusnahan manusia-manusia yang mempunyai cacat mental dan kekurangan sebagai bawaan genetik, karena mereka dianggap menghambat evolusi menuju ras unggul manusia.

${ }^{27}$ Stein, G., Biological science and the roots of Nazism, American Scientist 76(1) 1988, pp 50-58.
} 
bangsa-bangsa yang lemah. Secara ideologis pengaruh ini muncul dengan adanya ideologi Fascisme dan Komunisme yang mendasarkan pemikirannya berdasarkan persaingan dan konflik sosial.

Sebutan fasis pertama kali digunakan oleh Mussolini dan kelompok konservatif di Italia tahun 1919, yang membuat gerakan politik dengan menggabungkan ultranasionalisme dan anti ideologi Kiri. Pada tahun 1926 Mussolini mendirikan rezim berdasarkan kediktatoran secara penuh. Gerakan itu kemudian diikuti oleh partai Nazi di Jerman tahun 1929; serta menjadi partai berkuasa penuh di tahun 1033. Pemikiran dari Mussolini adalah menciptakan masyarakat 'totaliter'; sedangkan Hitler ingin menciptakan sebuah Utopia rasial (racial Utopia) yang diikuti dengan upaya penghapusan bangsa Yahudi dari Jerman serta penaklukan militer di Eropa Timur. Beberapa bangsa mencoba mengaplikasikan ide mengenai perjuangan untuk tetap survive kedalam politiknya; seperti Italia, Jerman dan juga Jepang. Yang terjadi selanjutnya adalah idea bahwa yang kuat akan tetap eksis dan bertahan sedangkan yang lemah akan dikalahkan dan lenyap. Dalam perkembangan selanjutnya, gerakan fasis juga muncul di banyak negara Eropa lainnya termasuk di Brazil, Amerika Latin. ${ }^{28}$

Dalam konteks politik internasional, pemikiran Darwinisme Sosial itu telah mendasari munculnya Perang Dunia I (1914-1920) dan juga Perang Dunia II (19391945) yang mengakibatkan korban ratusan juta orang. Munculnya Komunisme juga merupakan manifestasi dari Darwinisme Sosial ini. Komunisme yang mendasarkan pada konflik dan perjuangan kelas mengakibatkan perang berdasarkan fight for survival terjadi dan menyebar ke hampir seluruh dunia. Di bagian lain, kapitalisme yang berkembang di Barat mendapat pembenaran secara teoritik bahwa yang kuat akan eksis dengan melakukan penindasan terhadap yang lemah; dimana ini terwujud dengan meluasnya intoleransi, imperialisme dan kolonialisme ter hadap bangsa-bangsa di luar Eropa.

Sejumlah hal krusial perlu diperhatikan sebagai akibat dari munculnya Darwinisme Sosial ini. Pertama, terdapat sejarah yang mengerikan di masa lalu maupun

\footnotetext{
${ }^{28}$ Passmore, Kevin. 2002. Fascism: A Very Short Introduction, Oxford University Press: New York, p 11.
} 
sekarang berkaitan dengan penyalahgunaan biologi dalam ilmu dan kebijakan sosial. Peristiwa-peristiwa berkaitan dengan eugenics maupun genocide menjadi sejarah buruk dalam politik internasional. Ancaman keamanan internasional bukan lagi semata-mata keamanan sebuah negara atau bangsa (state security), namun lebih luas lagi adalah ancaman terhadap manusia itu sendiri secara langsung (human security). Korban manusia dalam konflik dan perang bukan lagi sebagai dampak ataupun ekses dari pertikaian di level negara; namun korban manusia itu adalah salah satu tujuan itu sendiri dari konflik. Dalam perspektif penganut Darwinisme sosial, ini dilakukan dalam rangka seleksi alam dimana yang kuat yang akan mampu bertahan, serta yang lemah akan hilang. Ini adalah proses evolusi masyarakat dunia versi penganut Darwinisme Sosial.

Kedua, menguatnya rasisme yang menyebabkan pertentangan berbasis masalahmasalah primordial menjadi semakin menguat dan diawetkan. Ini menjadi sesuatu yang mengkhawatirkan masa depan keamanan kehidupan manusia manakala prejudice dan stereotype akibat perbedaan-perbedaan yang sifatnya alamiah mendapat pembenarannya secara ilmiah. Dalam konteks normatif, ini merupakan degradasi yang besar dari ideal ilmu pengetahuan. Dalam satu bagian, perkembangan keilmuan diharapkan akan mampu mengatasi masalah-masalah akibat konflik sosial dan politik, namun di bagian lain justru muncul masalah baru ketika ilmu pengetahuan bersifat menantang (challenge) nilai-nilai kemanusiaan yang mendasar.

Ketiga, munculnya dinamika dunia bahwa persaingan yang terjadi diantara bangsa-bangsa; baik dalam segi politik, ekonomi, militer dan juga perluasan pengaruh, adalah bagian dari dimensi perjuangan untuk struggle and fight for life. Dalam konteks ini, menjadi nampak masuk akal ketika dominasi terjadi oleh kekuatan besar dan dominan terhadap kekuatan yang lemah (minor). Hal ini karena proses tersebut juga sesuai dengan pemikiran mengenai yang kuat yang akan akan eksis (survival of the fittest). 


\section{Darwinisme Sosial pasca Perang dunia II, Perang Dingin dan di era Milenium Baru}

Terdapat pandangan yang luas diantara para ilmuwan dan sejarawan bahwa Darwinisme sosial menurun popularitasnya pasca Perang Dunia II; yaitu ketika Darwinisme yang sifatnya diasosiasikan dengan rasisme dan juga Nazisme tidak mendapat tempat lagi di dunia. Keyakinan ini berdasar pada kuatnya konsensus demokratis yang muncul di negara-negara Barat yang hanya "sedikit" memberi toleransi pada teori yang memberi pembenaran biologis untuk rasisme, perang ataupun eksploitasi; yang menggambarkan bahwa Darwinisme Sosial sudah mati. Akan tetapi benarkah demikian? Apakah pada masa pasca Perang Dunia II 1945, Pasca Perang Dingin tahun 1989 dan periode sesudahnya di era millenium baru ini Darwinisme sosial tidak lagi eksis? Sejumlah fenomena menunjukkan bahwa Darwinisme Sosial masih tetap eksis dan kebijakan eugenics-pun masih ada di banyak tempat di masyarakat kapitalis modern pada abad ke-21 ini.

Pada pertengahan tahun 1960-an Darwinisme Sosial telah muncul kembali dan mendapatkan banyak pendengar (audiences) di Inggris maupun Amerika Serikat. Ini berkaitan dengan tulisan-tulisan popular mengenai warisan secara evolusioner yang berkaitan dengan studi "sociobiology" yang merupakan contoh penting bagi Darwinisme Sosial. Sosiobiologi berkaitan dengan studi tentang evolusi yang berasal tindakan-tindakan sosial. Sebagai sebuah disiplin keilmuan, sosiobiologi pertama kali didefinisikan oleh Edward O. Wilson dalam tulisannya Sociobiology: The New Synthesis (1972) mendefinisikan sosiobiologi "as the systematic study of the biological basis of all social behavior". ${ }^{29}$ Perkembangan pesat dari sosiobiologi, terutama di Amerika Serikat memberikan pelajaran yang penting untuk memahami sejarah Darwinisme Sosial; termasuk penolakan dalam lingkaran sosial (social circles) tertentu

\footnotetext{
${ }^{29}$ Wilson, Edward O.1975. Sociobiology: The New Synthesis, Belknap Press of Harvard University Press: New York, p 343.
} 
terhadap ide-ide dari Darwinisme, bukan kemudian menunjukkan ide-ide ini tidak lagi populer secara keseluruhannya. ${ }^{30}$

Teori evolusi modern merupakan struktur penjelasan dari pemikiran yang dibangun oleh Darwin. Teori modern ini menggabungkan genetika, ekologi, ethologi (ilmu perilaku hewan) dan juga matematika di dalam model dinamika evolusi. Palaentologi juga sangat relevan dengan teori pemikiran Darwin, terutama adalah ditemukannya fosil-fosil hominid di Afrika. ${ }^{31}$ Hasil dari teori evolusi modern ini lebih powerful namun lebih sukar dimengerti (abstruse) dibandingkan versi aslinya. Tulisan asli dari Darwin mudah dipahami oleh orang umum namun Darwinisme modern lebih sukar untuk diakses khalayak umum diluar bidang spesialisnya. Namun yang pasti darwinisme telah membangkitkan kontroversi umum dan juga perdebatan dikalangan para ilmuwan; yang sekaligus menggambarkan perkembangan dari teori evolusi hingga masa sekarang. Di dalam konteks inilah bidang studi "sosiobiology" muncul. Hal ini menunjukkan bahwa Darwinisme Sosial dapat mewujud di dalam bentuk pemikiran lain di era pasca Perang Dunia II, sehingga pandangan bahwa Darwinisme Sosial telah mengalami penurunan (decline) adalah terlalu dibesar-besarkan. ${ }^{32}$

\section{Darwinisme Sosial dan Isu Keamanan Dunia Kontemporer}

Selain dalam konteks biologis, Darwinisme Sosial telah termanifestasikam dalam banyak konflik politik Dunia yang mengancam keamanan global. Perlombaan senjata diantara negara-negara di dunia menjadi bukti bahwa esensi dari Darwinisme Sosial itu eksis. Perlombaan senjata di era Perang Dingin dan Pasca Perang Dingin menggambarkan tiga ajaran dari Darwin mengenai selesksi alamiah, struggle for life dan juga survival of the fittest. Di era Perang Dingin (1945-1989) terjadi pengkutuban negara-negara di dunia menjadi dua blok besar ideologi yaitu Liberal-kapitalis berhadapan dengan Komunisme. Sistem internasional pada masa Perang dingin ini

\footnotetext{
${ }^{30}$ Hawkins, op cit, p 294.

${ }^{31}$ Paleontologi adalah disiplin ilmu yang mempelajari mengenai sejarah kehidupan di bumi dan tanaman serta hewan purba berdasarkan fosil yang ditemukan di bebatuan. Istilah "hominid"digunakan dalam pengertian terbatas sebagai hominin atau "manusia dan kerabat dekat manusia yang lebih dekat dari pada simpanse".
} 
dikenali dengan sistem bipolar. Pada saat yang sama pertentangan ideologi ini disertai dengan perlombaan senjata, termasuk adalah perlombaan senjata pemusnah massal nuklir dan bom hidrogen. Mengapa perlombaan senjata itu berlangsung? Hal ini tidak lepas dari pemikiran bahwa yang kuat lah yang akan mampu untuk bertahan di dalam persaingan meneruskan eksistensi hidup di dunia internasional. Akibat selanjutnya adalah terjadi krisis keamanan dunia yang sangat serius, karena konflik ideologi dan perlombaan senjata itu menghadapkan umat manusia manusia menuju kemusnahan massal.

Di era pasca Perang Dingin dan Milenium Baru pun persaingan bangsa-bangsa di dunia masih terus berlanjut. Meskipun dasar ideologis bukan lagi menjadi sumber utama konflik, namun pertikaian berkaitan dengan struggle for life dan survival of the fittest terus berlangsung. Bahkan yang terjadi kemudian adalah semakin meluasnya aktor-aktor negara yang terlibat di dalam persaingan untuk menjaga survival dari negara dan bangsanya itu. Terdapat banyak negara baru yang muncul sebagai kekuatankekuatan baru di dunia. Hal ini berakibat pada semakin bervariasinya dimensi konflik yang terjadi, dan pada saat yang sama menjadi semakin kompleknya masalah berkaitan dengan kemanan dunia. Sistem internasional di era millenium baru ini menggambarkan bentuk sistem multi polar, dimana kutub-kutub kekuatan dunia tersebar ke banyak aktor-aktor negara.

Dalam konteks ekonomi, persaingan ekonomi Dunia pun menggambarkan esensi dari pemikiran Darwinisme ini. Negara yang kuat akan mendominasi sistem internasional, termasuk menguasai aset-aset penting yang menjaga kelangsungan hidup bangsanya sendiri meskipun merugikan bangsa lain yang posisinya lemah. Keunggulan ekonomi negara-negara besar mampu memaksa banyak negara lemah untuk terus bergantung kepada negara kuat. Hal ini menggambarkan pula dominasi yang kuat terhadap yang lemah; sebuah survival of the fittest.

Lebarnya gap antara negara-negara kaya dengan negara miskin berdampak pada keamanan internasional itu sendiri. Bagi negara-negara yang reaktif terhadap dominasi ini, mereka berupaya menentang kekuatan negara besar meskipun seringkali gagal. 
Sedangkan yang terpaksa berkolaborasi dengan negara yang kuat, maka negara-negara kecil akan menjadi subordinat negara besar demi tetap mampu mempertahankan eksistensinya.

Analisis ini menunjukkan bahwa Darwinise Sosial masih terus berlangsung hingga saat ini. Darwinisme Sosial bisa dimaknai bukan hanya dari sudut pandang pengaplikasian sosio-biology dalam praktek-praktek politik, ideologi dan pemerintahan secara langsung. Akan tetapi Darwinisme Sosial juga bermakna sebagai fenomenafenomena dalam politik internasional yang menggambarkan pemikiran dari konsepkonsep Darwinisme. Bangsa-bangsa di dunia berjuang untuk kelangsungan hidup mereka. Dalam hal ini mereka harus bersaing, terkadang melibatkan konflik dan perang dengan kekuatan bangsa lain. Dalam konteks seperti inilah, Darwinisme Sosial itu terus berlangsung dan menjadi dinamika realitas politik internasional. Ditinjau dari segi keamanan internasional, fenomena Darwinisme Sosial di dalam politik dunia seperti masa sekarang mengancam keamanan dunia baik dari segi keamanan negara (state security) maupun keamanan kelangsungan hidup manusianya (human security).

\section{Simpulan}

Darwinisme Sosial yang bersumber dari pemikiran ilmuwan biologi yaitu Charles Darwin telah berdampakm pada kehidupan manusia secara langsung. Dampak itu terjadi ketika pemikiran dari disiplin ilmu biologi, dalam hal ini adalah teori darwin tentang evolusi, diadopsi ke dalam pemikiran kehidupan sosial manusia. Sejarah mencatat bahwa pemikiran Darwinisme ini telah menginspirasi munculnya ideologi Fasis yang mendasarkan pandangannya pada teori Darwin mengenai seleksi alam, perjuangan mempertahankan hidup serta yang terkuat yang akan eksis. Di bagian lain, alur pemikiran yang dikonstruksi melalui evolusi Darwin tersebut menjadi pembenar dari munculnya ideologi yang berbasis pada konflik seperti Marxisme-Komunisme; termasuk ideologi yang penguasaan yang kuat atas yang lemah melalui imperialisme politik maupun ekonomi. 


\section{DAFTAR PUSTAKA}

Bartos, Otomar J. and Wehr, Paul. 2002. Using Conflict Theory, Cambridge University Press:New York.

Cassels, Alan. 1996. Ideology and international relations in the modern world, Routledge : London.

Clark ,Stephen R.L. (1999). The political animal: Biology, ethics and politics, Routledge: London.

Coolidge, Frederick L., and Wynn, Thomas., 2009. The Rise of Homo sapiens The Evolution of

Modern Thinking, John Wiley \& Sons Ltd: The Atrium UK.

Darwin,Charles.(2009). The Origin of Species :By Means of Natural Selection, or thePreservation of Favoured Races in theStruggle for Life, first published 1876,Cambridge University Press : New York.

Galtung, Johan.2007. Peace by peaceful conflict transformation - the

Transcend Approach, chapter 2 pp 14-32, in, Webel, Charles and Galtung,Johan (eds).2007. Handbook of Peace andConflict Studies, Routledge: New York.

Goldsmith, Timothy H.(1991). The biological roots of human nature: forging links between evolution and behavior, Oxford University Press : New York.

Hawkins, Mike.1997. Social Darwinism in European and American thought, 18601945: nature as model and nature as threat, Cambridge University Press : New York.

MacMaster, Neil.2001.Racism in Europe 1870-2000, Palgrave: New York.

Moore, J.R.1980. Varieties of Social Darwinism, Open University Course, Conflictand Stability in the Development of Modern Europe, Milton Keynes: Open University Press.

Passmore, Kevin. 2002. Fascism: A Very Short Introduction, Oxford University Press: New York.

Sapp, Jan, 2003. Genesis: The Evolution of Biology, Oxford University Press: New York

Stein, G., Biological science and the roots of Nazism, American Scientist 76(1) 1988, pp 50-58. 
Wilson, Edward O.1975. Sociobiology: The New Synthesis, Belknap Press of Harvard University Press: New York. 